Abstracta Iranica Abstracta Iranica

Revue bibliographique pour le domaine irano-aryen

Volume 29 | 2008

Comptes rendus des publications de 2006

\title{
Le soufi dans l'ivresse de la terminologie. Préface de Pierre Lory, Paris, L'Harmattan, 2006, 108p.
}

\section{Ève Feuillebois-Piérunek}

\section{(2) OpenEdition}

1 Journals

\section{Édition électronique}

URL : http://journals.openedition.org/abstractairanica/30492

DOI : 10.4000/abstractairanica.30492

ISSN : 1961-960X

Éditeur :

CNRS (UMR 7528 Mondes iraniens et indiens), Éditions de l'IFRI

\section{Édition imprimée}

Date de publication : 15 mai 2008

ISSN : 0240-8910

\section{Référence électronique}

Ėve Feuillebois-Piérunek, «Le soufi dans l'ivresse de la terminologie. Préface de Pierre Lory, Paris, L'Harmattan, 2006, 108p. », Abstracta Iranica [En ligne], Volume 29 | 2008, document 295, mis en ligne le 15 septembre 2008, consulté le 25 septembre 2020. URL : http://journals.openedition.org/ abstractairanica/30492 ; DOI : https://doi.org/10.4000/abstractairanica.30492

Ce document a été généré automatiquement le 25 septembre 2020

Tous droits réservés 


\title{
Le soufi dans l'ivresse de la terminologie. Préface de Pierre Lory, Paris, L'Harmattan, 2006, 108p.
}

\author{
Ève Feuillebois-Piérunek
}

1 L'A. pose la question de la transmission fidèle du message soufi au lecteur occidental à travers l'exemple des traductions de termes techniques soufis proposés par Jean Chevalier dans ses ouvrages, Le Soufisme et la tradition islamique, et Le Soufisme ou l'ivresse de Dieu dans la tradition de l'Islam (1974). Il a manqué à Jean Chevalier la formation philologique qui lui aurait permis d'éviter maintes erreurs d'interprétations dues à l'ignorance de l'étymologie et du contexte coranique et soufi des mots. Elle lui oppose le plus souvent les termes choisis par Eric Geoffroy.

2 Après une sommaire introduction sur le soufisme et son langage symbolique, elle aborde successivement le cas de $\underline{d} e k r$ (remémoration), sama $\bar{a}^{\prime}$ (concert spirituel), fan $\bar{a}^{\prime}$ (annihilation de la conscience individuelle dans la Présence divine), sokr (ivresse spirituelle), morìd (aspirant sur la Voie), šeyH (guide spirituel). Elle conclut en lançant un appel à la normalisation de la traduction de la terminologie soufie, semblant ignorer que la recherche occidentale sur le soufisme a considérablement avancé depuis les ouvrages de vulgarisation de Jean Chevalier et que la traduction des termes qu'elle traite fait depuis longtemps l'objet d'un consensus dans la communauté scientifique.

3 Au regard de l'indigence de sa bibliographie et de sa connaissance approximative du sujet (on lit notamment cette surprenante remarque, " Il ne faut pas confondre les derviches tourneurs avec les soufis »), on pourrait reprocher à Hanan Mounib les mêmes travers que ceux qu'elle relève chez Jean Chevalier. 
INDEX

Thèmes : 8. Soufisme

\section{AUTEURS}

ÈVE FEUILLEBOIS-PIÉRUNEK

Sorbonne Nouvelle-Paris III / Mondes iranien et indien 